\title{
Indigenous social and economic adaptations in northern Alaska as measures of resilience
}

\author{
$\underline{\text { Stephanie Martin }}^{1}$
}

\begin{abstract}
I explored one aspect of social-ecological change in the context of an Alaskan human-Rangifer system, with the goal of understanding household adaptive responses to perturbations when there are multiple forces of change at play. I focused on households as one element of social resilience. Resilience is in the context of transition theory, in which communities are continually in a process of change, and perturbations are key points in the transition process. This case study of Anaktuvuk Pass, Alaska, USA, contributes to the understanding of cultural continuity and household resilience in times of rapid change by using household survey data from 1978 to 2003 to understand how households adapted to changes in the cash economy that came with oil development at the same time as a crash in the caribou population and state-imposed limits on caribou harvests. The research illustrates that households are resilient in the way they capture opportunities and create a new system so that elements of the old remain while parts change.
\end{abstract}

Key Words: Anaktuvuk Pass; resilience

\section{INTRODUCTION}

This research explores one aspect of social-ecological change in the context of an Alaskan human-Rangifer system (HRS), with the goal of understanding how households respond to perturbations during times of rapid change. It is a case study of the community of Anaktuvuk Pass, Alaska, USA, from the mid-1970s to 2003. In this study, resilience is defined as a system's capacity to maintain its fundamental structure and functioning despite perturbations (Cumming et al. 2005, Folke 2006, Kofinas et al. 2010, Wilson 2012). I focus on households as one element of social resilience (Adger 2000) while recognizing that the study community is reliant on ecosystem services (Berkes and Jolly 2001, Folke 2006). I view resilience in the context of transition theory (Wilson 2012), in which communities are continually in a process of change. Disruptions, perturbations, stresses, or shocks are key points in the transformation process (Wilson 2012). I examine perturbations and follow Turner et al. (2003), who define perturbation as a disturbance that originates beyond the system. In contrast, stresses originate within the system. McCarthy and Martello (2005) and others (Folke 2006, Wilson 2012) note that changes can have both positive and negative effects and can create opportunities for innovation and development. Adaptations are structural changes in response to external circumstances (Young et al. 2006). In this study, adaptations are changes that households make in their productive activities to minimize risk to their resources and livelihoods (Berkes and Jolly 2001, McCarthy and Martello 2005).

In the case of Anaktuvuk Pass, a community with a subsistencecash economy, households moved from relying primarily on ecosystem services to being connected to the global economy while remaining reliant on the local ecosystem. During the study period, households diversified, and movement was from a simple to a more complex economic society (Wilson 2012) while maintaining essential elements of the former. The embedded assumption that complex society is a more resilient society remains an open question (Timmerman 1981, Turner et al. 2003). Adaptive responses of households allowed them to persist during the period of perturbation. Following the perturbation, households incorporated wages from jobs into a subsistence- based economy to create a mutually reinforcing mixed economic system in which elements of the old remained while the parts changed (Anderies et al. 2004).

Perturbations had two forms: restrictions on caribou hunting and increased job opportunities. I identified the mid-1970s as the period of perturbation for the community of Anaktuvuk Pass. A short but severe disruption to harvests came in 1976, when the Alaska Department of Fish and Game (ADFG) imposed limits on caribou hunters in response to a perceived crash in the caribou population. During this same period, oil production started at Prudhoe Bay, Alaska, bringing jobs and transfer income to Anaktuvuk Pass residents. Nearly all residents work for the North Slope Borough (NSB) rather than directly for oil companies. The borough was established in 1972 and began to levy taxes on oil infrastructure located on borough land. To generate cash quickly, the borough began to issue bonds, and over time used tax revenue to repay them. Bond revenue provides funding for major infrastructure improvement projects (Morehouse et al. 1984). The projects preferentially hire borough residents.

During the time when caribou harvests were restricted, households incorporated wages from jobs into the socialeconomic system. Households returned to caribou harvesting after restrictions were lifted, but also maintained income-earning jobs. I view households as integral to the system, highly dynamic, and as both responding to formal institutional change affecting the HRS (Kofinas and Russell 2004) and greater global economic change. In the North American context, transformation of a socioeconomic system is defined as a transition from seminomadic caribou hunters to a hybrid economy mixing subsistence hunting and fishing, transfer income, and wages. The existence and durability of a mixed economy in rural Alaska has been well documented by other researchers (VanStone 1960, Kruse 1991, Kirkvliet and Nebesky 1997, Magdanz et al. 2004, Wolfe 2004, Wolfe et al. 2009). I also report community-level demographic measures identified by Adger (2000) as indicators of resilience. My research questions were: What adaptive strategies did households use in response to hunting limits imposed in 1976 ? How can sustained caribou harvests and sharing be seen as 
household-level proxies for resilience? Are there indicators of community-level resilience corresponding to household changes? Have households in this HRS undergone a transition?

\section{METHODS}

\section{Study area}

In this section, I describe the study area, its residents, and its fundamental structure, and identify essential elements that, if impaired, would threaten its continued existence (Timmerman 1981, Anderies et al. 2004, Cumming et al. 2005). For Anaktuvuk Pass, the essential elements are household caribou hunting, cultural continuity, and community-level demographic stability. Anaktuvuk Pass is located in the Brooks Range of Alaska's North Slope, USA, and is situated in a caribou migration corridor (Fig. 1). Caribou migrate in the spring and fall (Brower and Hepa 1998). The 2010 community population of 324 is predominantly Iñupiat (Inuit of Alaska). The community is accessible by air in summer and by air or snow machines in winter.

Fig. 1. Map of Alaska, USA, showing Anaktuvuk Pass.

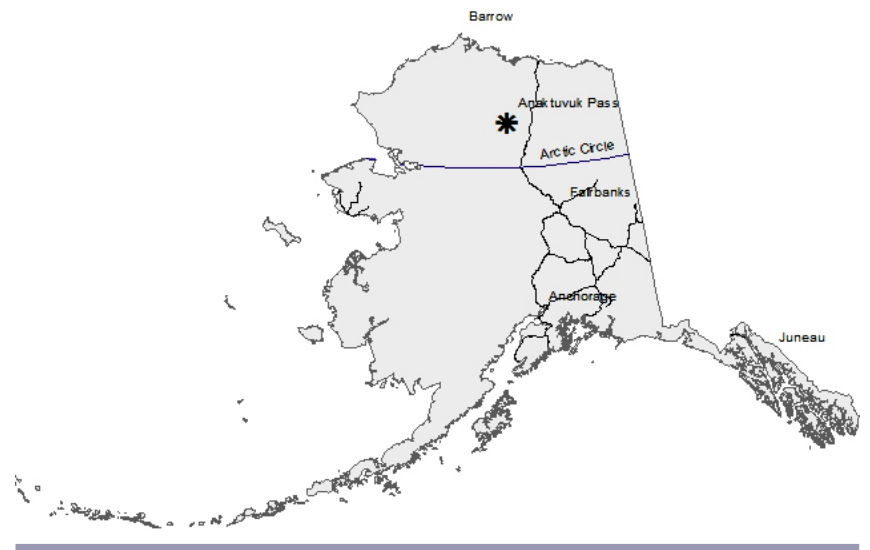

Hall et al. (1985) provide a historical overview of community settlement, reporting that Iñupiat caribou hunters have been living and hunting caribou in the interior part of what is now the North Slope borough since the 1400s. Although caribou make up the largest share of subsistence harvests, local residents also harvest fish, birds, moose, sheep, plants, and berries. Since the Anaktuvuk Pass area was first inhabited in the 1800s, residents relied primarily on a single resource for subsistence needs, making the community potentially more vulnerable to disruptions compared to multi-resource communities on the coast (Adger 2000). In the early 1900s, the caribou population collapsed, and Iñuiat people either died of starvation or moved away (Hall et al. 1985). Moving away from the Anaktuvuk Pass area is evidence of mobility as a resilience characteristic. Mobility has been recognized as a key resilience strategy for households prior to permanent settlements (Berkes and Jolly 2001, McCarthy and Martello 2005).

By the 1920s, the caribou population began to recover, and 10 years later, people returned to hunt during winter. During the 1940s, several families returned, and by 1950 , the population was 66(U.S. Bureau of the Census, no date). At that time, store-bought foods were not available, and people traveled by dog team. In 1968, oil was discovered at Prudhoe Bay, and decades of rapid change followed. In 1970, 99 people lived in Anaktuvuk Pass, and all but two were Alaska Native (U.S. Census 1970, summary file 4 [U.S. Bureau of the Census 1996]). The population more than doubled to 203 by 1980 (U.S. Census 1980, summary file 3 [U.S. Bureau of the Census 2008]), and has increased steadily since then (U.S. Census 1990 and 2000, summary file 3 [U.S. Bureau of the Census 1993, U.S. Bureau of the Census 2002]). Today, approximately 9 out of 10 residents are Alaska Native (U.S. Bureau of the Census 2012).

With oil production and the creation of local and regional governments came job opportunities and wage earnings. Local and borough government jobs allowed for subsistence leave and scheduled work around community calendars. In 1980, 1990, and 2000, no one from Anaktuvuk Pass worked at Prudhoe Bay (measured by travel time to work using U.S. Census summary file 3 computer files), possibly because oil production takes place in an industrial enclave, with two weeks on and two weeks off, and with no accommodations for subsistence. No data are available for 2010 because the U.S. Census discontinued use of the long form, which included questions about income, education, occupation, travel time to work, migration, disabilities, and language.

At about the same time as economic development was gaining momentum, big changes were coming for caribou harvests. Statewide economic growth and institutional development led to tension between state government and traditional subsistence communities (Morgan 1976, Morehouse et al. 1984, Spaeder 2005, Spaeder and Feit 2005, Dayo and Kofinas 2010). Until the 1970 s, there were no seasonal restrictions or bag limits for caribou. In 1976, the State of Alaska began to implement management plans for caribou by imposing per-hunter limits and seasonal closings; this was a shock to the people of Anaktuvuk Pass, who relied on caribou as their primary food source and food sharing as a cultural tradition. ADFG officials cited a catastrophic drop in the population of the Western Arctic Caribou herd as the reason for the limits (Fig. 2). According to ADFG, the herd numbered 242,000 in 1970 and declined to $<100,000$ by 1976 (Morgan 1976). However, there was a common opinion by local native hunters that the population census was flawed and therefore inaccurate (Kruse et al. 1998).

Fig. 2. Population estimates for the Western Arctic Caribou herd. Source: Western Arctic Caribou Herd Working Group (2003), Woodford (2012).

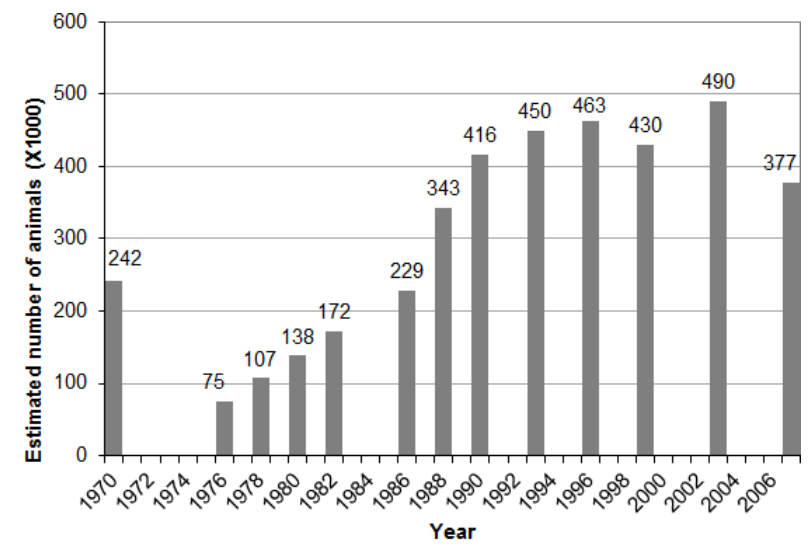


Caribou is the key subsistence species for Anaktuvuk Pass households. The absence of animals disrupted subsistence practices. Subsistence involves cultural values and attitudes, mutual respect, sharing, resourcefulness, and an understanding (both conscious and mystical) of the intricate interrelationships that link humans, animals, and the environment (Alaska Natives Commission 1994). In Anaktuvuk Pass, as in other rural Alaska communities, harvest sharing is not only a cultural tradition, but is also a result of efficient production. ADFG subsistence harvest data show a consistent pattern of harvest sharing in Anaktuvuk Pass. Approximately one-half of households reported hunting, and nearly all hunters reported sharing their harvests (Community Harvest Subsistence Information System data files, ADFG 2013). This behavior is consistent with subsistence harvest patterns elsewhere in rural Alaska. In an analysis of subsistence harvest data across rural Alaska, Wolfe and Walker (1987) found that $\sim 30 \%$ of households account for $70 \%$ of the harvest, with wild foods distributed to other households in the community, a pattern known as the 30:70 rule. Writing about Anaktuvuk Pass, Brower and Opie (1996) describe community feasts where successful hunters distribute their harvest to other people in the community. For Anaktuvuk Pass, a relatively small number of hunters traditionally produce most of the harvest. This practice magnified the hardship of government-imposed per-hunter bag limits.

\section{Data sources}

Data sources for proxy measures of resilience come from four household censuses, two household sample surveys (a randomly selected subset of households), and ADFG subsistence harvest surveys. The ADFG surveys ask a series of questions about each species. In the case of caribou, the questions are: Did your household use caribou? ("Use" includes using meat for human and animal food, as well as hides, antlers, and other caribou parts for clothing, art, and other purposes). Did your household attempt to harvest caribou? Did your household harvest caribou? Did your household give away any caribou? Did your household receive any caribou? ADFG survey methodology is described in detail by Fall (1990).

Household survey data include only Alaska Native households, defined as having at least one adult who self-identifies as Alaska Native. The NSB conducted a sample survey in 1978 and censuses in 1988, 1993, 1998, and 2003. Sample survey data were also obtained from the 2003 Survey of Living Conditions in the Arctic (SLiCA; Kruse et al. 2008), which is a household survey of aboriginal people in the Arctic. The survey included aboriginal households in the United States (Alaska), Canada, Greenland, Norway, Sweden, Finland, and Russia (Chukotka and the Kola Peninsula); the Alaska and Russian portions of the survey were funded by the National Science Foundation (http://www. arcticlivingconditions.org/). Martin (2010) discusses the survey in more detail.

The 1978 NSB survey is interesting because it covers the time when caribou hunting limits were in place and includes questions about how households adapted to the limits. However, it did not ask people if they hunted caribou in 1977 because of sensitivity and confusion about the regulation. Nearly all surveys included household demographics, employment, income, housing, hunting and fishing activities, and subsistence food consumption. SLiCA and the NSB 2003 census took place in the same year. Where possible, I used data from the NSB census because it contains information on 92 households, whereas the SLiCA sample is 10 households.

\section{RESULTS}

Caribou harvest level is a measure of household resilience. Survey data indicate that hunting restrictions disrupted harvests and food supply (Table 1). Of the households in the NSB 1978 survey, $71 \%$ reported that they hunted caribou prior to the imposed limits. Nearly all households $(96 \%)$ reported that they had less food during the restrictions than in the prior period, and 96\% reported that the caribou regulations were the reason why. Hall et al. (1985) wrote that in 1976, hunters chartered an airplane to find caribou. However, this strategy did not overcome the problem of bag limits and was very expensive. During the time of the ban, households adapted to imposed limits by eating more store-bought food, by eating less meat, or both, and households did not substitute other subsistence foods for caribou (Table 2). Hall et al. (1985) also noted that there are few good fishing locations nearby.

Table 1. Food consumption characteristics for Anaktuvuk Pass 1990-1994 and 2006. Source: Community Harvest Subsistence Information System data files (ADFG 2013) and 1978 North Slope survey (unpublished data).

\begin{tabular}{lc}
\hline \hline Food consumption characteristics & Households $(\%)^{\dagger}$ \\
\hline $\begin{array}{l}\text { Household hunted caribou prior to } \\
\text { imposition of harvest limits }\end{array}$ & 71.4 \\
Household reported less food in 1977 than in & 96.4 \\
1970 & 96.4 \\
Household reported that change in food & \\
amount was due to caribou harvest limits & \\
Coping mechanisms & 3.7 \\
Household hunted other species and fish & 44.4 \\
Household bought more meat & 18.5 \\
Household ate less meat & 14.8 \\
Household hunted other species and bought & \\
more food & 3.7 \\
Household ate less and bought more food & 3.7 \\
Harvest limits had no effect on household & \\
${ }^{\dagger} N=28$ households. &
\end{tabular}

Table 2. Caribou harvests for Anaktuvuk Pass 1990-1994 and 2006. Source: Community Harvest Subsistence Information System data files (ADFG 2013).

\begin{tabular}{lcc}
\hline \hline Year & $\begin{array}{c}\text { Total number of } \\
\text { caribou harvested }\end{array}$ & $\begin{array}{c}\text { Per capita number of } \\
\text { caribou harvested }\end{array}$ \\
\hline 1990 & 592 & 2.3 \\
1991 & 545 & 2.0 \\
1992 & 600 & 2.2 \\
1993 & 574 & 1.9 \\
1994 & 311 & 1.1 \\
2006 & 596 & 2.0 \\
\hline
\end{tabular}


Despite the disruption caused by the imposition of hunting limits in 1976, households returned to caribou hunting after the restrictions were lifted (Table 2). Except for 1994, the number of animals harvested has been fairly constant over the 16 years. In addition to counts of animals harvested, the 2006 survey also contained information about households. Nearly everyone in the community, i.e., $92 \%$ of households, reported using caribou.

Cultural continuity is another measure of household resilience. I used data on household participation in a broad range of subsistence activities over time, household consumption of subsistence foods, and harvest sharing as indicators of cultural continuity. Households reported that they maintained subsistence activities, consumption, and sharing over the 25-year period (e.g., fishing, hunting caribou, gathering berries, sewing skins, trapping, and hunting marine mammals; Fig. 3). A high percentage of respondents reporting that they participated in marine mammal harvests in 2003 is due to the small sample size; two households reported hunting for seals. Participation levels in non-caribou subsistence activities were similar in 1978 to subsequent years, indicating that in 1978, people did not shift from caribou harvests to other activities. In 1978, no one reported that they participated in whaling, walrus, or seal hunting. This is consistent with the lack of alternative subsistence resources nearby, the expense of equipment and travel, and lack of knowledge specific to some harvests (e.g., marine mammals). It is also consistent with the observation by Wolfe (2004) that culture determines which species will be harvested. For the 12 months prior to each survey, $>50 \%$ of households reported that one-half or more of their subsistence food came from their own harvests (Table 3). This share has not decreased over time. In addition, since $1978, \geq 71 \%$ of households report that they gave subsistence food to other households, and $>$ $80 \%$ of households reported that they received food over the previous 12 months (Table 3).

Fig. 3. Percentage of adults participating in subsistence activities. Bars indicate the range of the estimates. Source: North Slope Borough census 1978, 1988, and 1993 (unpublished data), Survey of living conditions in the Arctic 2003 (unpublished data).

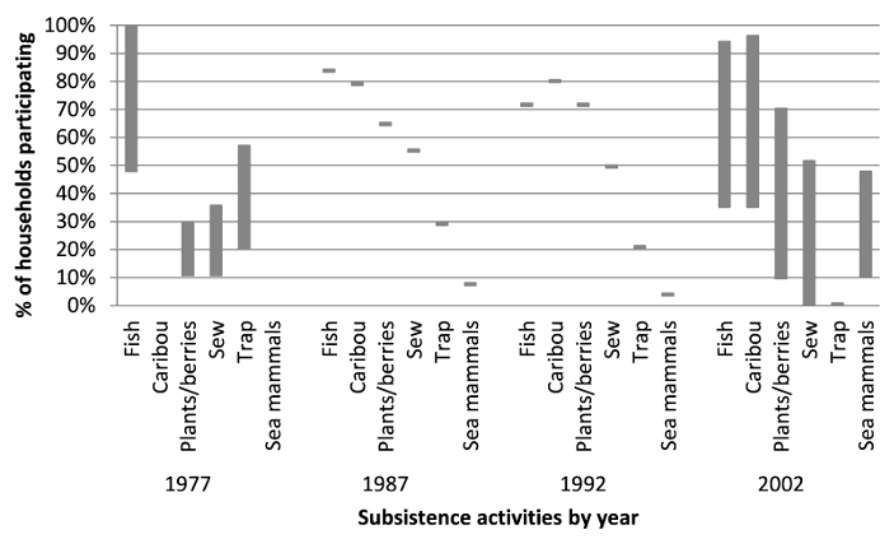

Table 3. Household hunting, harvesting, and food sharing characteristics. Source: North Slope Borough 1978, 1988, 1993, and 2003 (unpublished data).

\begin{tabular}{lcccc}
\hline \hline & \multicolumn{4}{c}{ Year } \\
\cline { 2 - 5 } Characteristic & 1978 & 1988 & 1993 & 2003 \\
\hline Household hunted (\%) & $57 \pm 18$ & 50 & 57 & $67 \pm 29 \dagger$ \\
Household gave food to other & $53 \pm 18$ & 71 & 76 & 82 \\
households (\%) & & & & \\
Household received food (\%) & $61 \pm 18$ & 80 & 87 & 83 \\
One-half or more of meat and & $57 \pm 18$ & 50 & 57 & $67 \pm 29 \dagger$ \\
fish from own harvest (\%) & & & & \\
Number of households surveyed & 28 & 72 & 69 & 78 \\
\hline
\end{tabular}

$\uparrow$ Source: Survey of living conditions in the Arctic 2003 (unpublished data), $N=10$.

\section{Material well-being}

In 1970, 10 people (approximately 13\% of the population aged 16-69) worked at wage jobs during the previous 12 months, and per capita income was $<\$ 100$ USD (U.S. Census 1970, summary file 4 computer file [U.S. Bureau of the Census 1996]). By 1980, 45 people had wage jobs, and per capita income had risen to approximately $\$ 11,000$ USD (U.S. Census 1980, summary file 3 computer file [U.S. Bureau of the Census 2008]). Compared to 1970, employment increased sharply during the 1970s and remains at high levels, with nearly 9 out of 10 working-age people holding jobs during the previous 12 months (Table 4). Combining caribou harvest information (Table 2) and employment data (Table 4) from 1978 suggests that during the caribou shortage, people went to work and used wage earnings to buy more food. In the years following 1978, people continued to work after the hunting restrictions were lifted (Table 4).

Table 4. Percentage of 16-69-year-old residents of Anaktuvuk Pass with full- or part-time jobs, 1978-2003. Source: North Slope Borough census 1978, 1988, 1993, and 2003 (unpublished data).

\begin{tabular}{lcc}
\hline \hline Year & Employment (\%) & $N$ \\
\hline 1978 & $68 \pm 17$ & 28 \\
1988 & 88 & 125 \\
1993 & 85 & 109 \\
1998 & 87 & 108 \\
2003 & 78 & 162 \\
\hline
\end{tabular}

\section{Mixed economy}

Household participation in wage earning and subsistence activities is a household adaptive strategy. Once the hunting restrictions were lifted, households returned to caribou hunting but retained jobs, marking the emergence of a hybrid mixed subsistence-cash economy, which extended beyond earnings from trapping to includes wage and salary earnings. The move to a mixed economy was not so much the result of hunting restrictions as it was of a significant increase in job opportunities. Increasingly, subsistence hunters need cash to help support their traditional way of life (Kruse 1991, Kirkvliet and Nebesky 1997, 
Berman 2009). Cash also supports modern conveniences that have become part of Iñupiat life. Rifles have replaced bows and arrows, snow machines have replaced dog teams, and freezers improve food storage. Jobs provide money for equipment, fuel, and ammunition. Technological advances have also made hunting and fishing more efficient, allowing people to live in villages near jobs and schools, and hunt and fish on the weekends or in their spare time (Berman and Kofinas 2004). Taken together, increased employment, improved but more expensive equipment, and continued subsistence indicate that households are using some of their wage earnings for subsistence activities. By 1978, 57\% of households participated in the wage economy and subsistence hunting and fishing, similar to later years (Fig. 4).

Fig. 4. Household mix of jobs and subsistence activities for Anaktuvuk Pass. Source: North Slope Borough census 1978, 1988, and 1993 (unpublished data), Survey of living conditions in the Arctic 2003 (unpublished data).

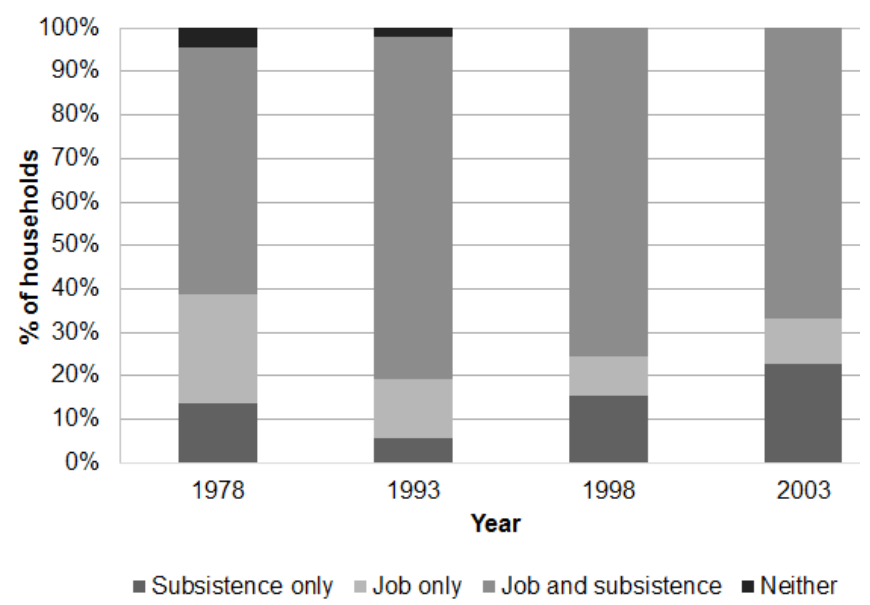

As oil and tax revenues began to flow to the state of Alaska, the NSB, and the Arctic Slope Regional Corporation (ASRC), households began receiving dividend payments, adding to the mix of cash and subsistence. Beginning in 1972, ASRC began paying shareholder dividends. In 2009, ASRC paid out approximately $\$ 5700$ (USD) per person to 9600 shareholders (State of Alaska 2011). In 1982, households in Anaktuvuk Pass began receiving additional income when the Permanent Fund Dividend program began to make annual payments to every Alaskan from oil revenue earnings (Alaska Permanent Fund Corporation 2013, unpublished report).

\section{Population stability}

Following Adger (2000), I used stable age structure and slow but continued population growth as indicators of community level resilience. Anaktuvuk Pass is more than five-times as large as it was in 1950, and 9 out of 10 people are Alaska Native. Even during the mid-1970s, the population increased despite the drop in caribou availability. This is in sharp contrast to the turn of the century, when people left the area after the caribou population crashed. Unlike some communities in which nearly all the young Alaska Native women have left (Martin 2009), there are nearly equal numbers of young adult men and women in Anaktuvuk
Pass (Fig. 5). Relatively large numbers of 10-19-year-olds indicate that, if conditions remain the same (including the cost of living), the population could be stable in future years, and there are enough young adults to maintain caribou harvest traditions.

Fig. 5. Age and sex structure of the Anaktuvuk Pass population, 2010. Source: U.S. Census Bureau (2012: summary file 1 computer file).

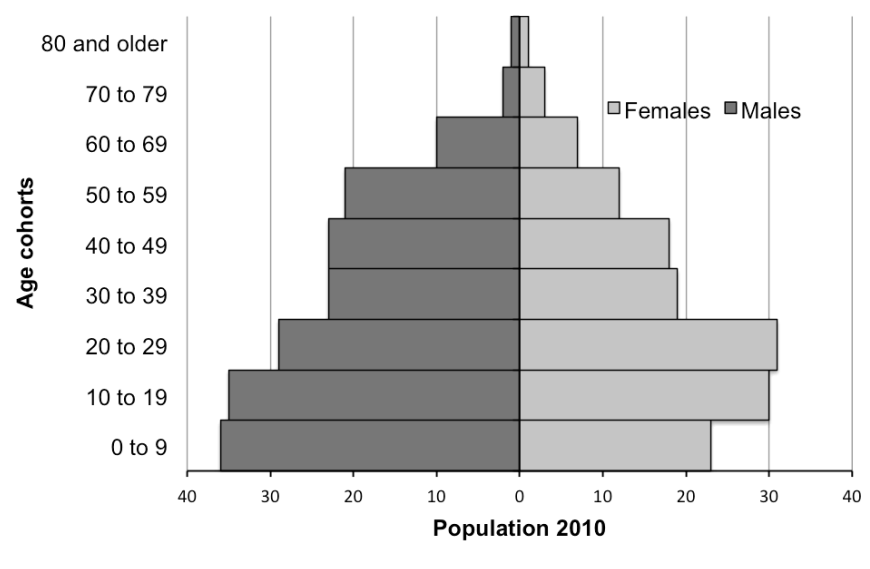

\section{DISCUSSION}

I presented modest empirical evidence to support a simple idea: changing adaptive strategies helps households rebound from perturbations. Adaptive strategies that promote the ability to rebound involve incorporating new opportunities while maintaining key cultural and social functions. In this case, households adapted to a perturbation, i.e., hunting restrictions, by taking advantage of job opportunities and substituting storebought for harvested foods. Following the perturbation, households incorporated earnings from jobs into the subsistence economy and returned to caribou harvesting and associated sharing traditions, and at the same time, they created a highly integrated mixed cash-subsistence economy. During the time span of this study (1978-2010), while households were adapting to change and incorporating new opportunities, the population of Anaktuvuk Pass continued to grow, and the age-sex structure of the community remained stable. The response to the disruption in 1970 was different from the outmigration and starvation of the early 1900s, possibly because of the availability of wage earnings to maintain food supply. The mixed economy connects households of Anaktuvuk Pass to the global economy while continued caribou hunting and harvest sharing maintains their connection to the HRS. This research shows how households adapted to disturbances from the combination of worldwide economic, ecological, and state-initiated institutional changes. The households of Anaktuvuk Pass have demonstrated resilience in the sense that they incorporated new resources to maintain Rangifer harvest while increasing material well-being. Households have taken advantage of the opportunities that came from rapid change to manage vulnerability and risk.

According to Cumming et al. (2005), one of the aims of applying resilience theory to empirical case studies is to identify strategies for continued resilience. The lessons from Anaktuvuk Pass in the 
1970s may be, as Holling (1973) writes, to maintain flexibility above all else. The work of Ostrom (1990) and others (Anderies et al. 2004) indicates that the best way to maintain flexibility is to allow for those who have the highest stakes in the system to have the strongest voices in regulation. Continued pressure on the HRS in Anaktuvuk Pass comes from climate change related events and changes in the global economy (Kofinas and Russell 2004). Increased fire frequency and intensity could damage lichendominated habitats on which caribou rely (Joly et al. 2011). Rising fuel prices are driving up transportation costs as well as rapid increases in the cost of living (Fried and Robinson 2008). High fuel prices and other costs have put pressure on households by making hunting more expensive while forcing them to rely more on subsistence foods (Brinkman et al. 2014). How these factors will affect households in the HRS are subjects for future research.

Responses to this article can be read online at: http://www.ecologyandsociety.org/issues/responses. $\mathrm{php} / 7586$

\section{Acknowledgments:}

I extend a special thank you to the anonymous reviewers of this manuscript.

\section{LITERATURE CITED}

Adger, W. N. 2000. Social and ecological resilience: are they related? Progress in Human Geography 24(3):347-364. http://dx. doi.org/10.1191/030913200701540465

Alaska Department of Fish and Game (ADFG). 2013. Community subsistence harvest information system. Alaska Department of Fish and Game, Juneau, Alaska, USA. [online] URL: http://www.adfg.alaska.gov/sb/CSIS/.

Alaska Natives Commission. 1994. Alaska Native Commission, final report, volume I. Alaska Federation of Natives, Anchorage, Alaska, USA. [online] URL: http://www.alaskool.org/resources/ anc/anc toc.htm.

Anderies, J. M., M. A. Janssen, and E. Ostrom. 2004. A framework to analyze the robustness of social-ecological systems from an institutional perspective. Ecology and Society 9(1):18. [online] URL: http://www.ecologyandsociety.org/vol9/iss1/art18.

Berkes, F., and D. Jolly. 2001. Adapting to climate change: socialecological resilience in a Canadian western Arctic community. Conservation Ecology 5(2): 18. [online] URL: http://www. consecol.org/vol5/iss2/art18.

Berman, M. 2009. Moving or staying for the best part of life: theory and evidence for the role of subsistence in migration and well-being of Arctic Inupiat residents. Polar Geography 32 (1-2):3-16. http://dx.doi.org/10.1080/10889370903000356

Berman, M., and G. Kofinas. 2004. Hunting for models: grounded and rational choice approaches to analyzing climate effects on subsistence hunting in an Arctic community. Ecological Economics 49(1):31-46. http://dx.doi.org/10.1016/j.ecolecon.2003.12.005
Brinkman, T., K. B. Maracle, J. Kelly, M. Vandyke, A. Firmin, and A. Springsteen. 2014. Impact of fuel costs on high-latitude subsistence activities. Ecology and Society 19(4):18. http://dx.doi. org/10.5751/ES-06861-190418

Brower, H. Jr., and T. Hepa. 1998. Subsistence hunting activities and the Inupiat Eskimo. Cultural Survival Quarterly 22(3) (Fall 1998). [online] URL: http://www.culturalsurvival.org/publications/ cultural-survival-quarterly/united-states/subsistence-hunting-activitiesand-inupiat-es.

Brower, H. K. Jr., and R. T. Opie. 1996. North Slope Borough Subsistence Harvest Documentation Project: data for Anaktuvuk Pass, Alaska for the period July 1, 1994 to June 30, 1995. North Slope Borough Department of Wildlife Management, Barrow, Alaska, USA. [online] URL: http://www.north-slope.org/assets/ images/uploads/Subsistence $\% 20$ Harvest $\% 20$ Doc $\% 20$ Report AKP 94-95. pdf.

Cumming, G. S., G. Barnes, S. Perz, M. Schmink, K. E. Sieving, J. Southworth, M. Binford, R. D. Holt, C. Stickler, and T. Van Holt. 2005. An exploratory framework for the empirical measurement of resilience. Ecosystems 8(8):975-987. http://dx. doi.org/10.1007/s10021-005-0129-Z

Dayo, D., and G. Kofinas. 2010. Institutional innovation in less than ideal conditions: management of commons by an Alaska Native village corporation. International Journal of the Commons 4(1):142-159. [online] URL: http://www.thecommonsjournal. org/index.php/ijc/article/view/146/101.

Fall, J. A. 1990. The Division of Subsistence of the Alaska Department of Fish and Game: an overview of its research program and findings: 1980-1990. Arctic Anthropology 27 (2):68-92. [online] URL: http://www.jstor.org/stable/40316227.

Folke, C. 2006. Resilience: the emergence of a perspective for social-ecological systems analysis. Global Environmental Change 16(3):253-267. http://dx.doi.org/10.1016/j.gloenvcha.2006.04.002

Fried, N., and D. Robinson. 2008. The cost of living in Alaska. Alaska Economic Trends 28(7):4-15. [online] URL: http://labor. state.ak.us/trends/trends2008.htm.

Hall, E., S. C. Gerlach, and M. Blackman. 1985. In the national interest: a geographically based study of Anaktuvuk Pass Iñupiat subsistence through time. Volumes 1 and 2. North Slope Borough, Barrow, Alaska, USA.

Holling, C. S. 1973. Resilience and stability of ecological systems. Annual Review of Ecology and Systematics 4:1-23. http://dx.doi. org/10.1146/annurev.es.04.110173.000245

Joly, K., D. R. Klein, D. L. Verbyla, T. S. Rupp, and F. S. Chapin III. 2011. Linkages between large-scale climate patterns and the dynamics of Arctic caribou populations. Ecography 34 (2):345-352. http://dx.doi.org/10.1111/j.1600-0587.2010.06377.x

Kirkvliet, J., and W. Nebesky. 1997. Whaling and wages on Alaska's North Slope: a time allocation approach to natural resource use. Economic Development and Cultural Change 45 (3):651-665. http://dx.doi.org/10.1086/452295

Kofinas, G., and D. Russell. 2004. North America. Pages 21-52 in B. Ulvevadet and K. Klokov, editors. Family-based reindeer 
herding and hunting economies, and the status and management of wild reindeer/caribou populations. Centre for Saami Studies, University of Tromsø, Tromsø, Norway.

Kofinas, G. P., F. S. Chapin III, S. BurnSilver, J. I. Schmidt, N. L. Fresco, K. Kielland, S. Martin, A. Springsteen, and T. S. Rupp. 2010. Resilience of Athabascan subsistence systems to interior Alaska's changing climate. Canadian Journal of Forestry 40 (7):1347-1359. http://dx.doi.org/10.1139/X10-108

Kruse, J. 1991. Alaska Iñupiat subsistence and wage employment patterns: understanding individual choice. Human Organization 50(4):317-326. http://dx.doi.org/10.17730/humo.50.4.c288gt2641286g71

Kruse, J., D. Klein, S. Braund, L. Moorehead, and B. Simeone. 1998. Co-management of natural resources: a comparison of two caribou management systems. Human Organization 57 (4):447-458. http://dx.doi.org/10.17730/humo.57.4.q5825utw35841p11

Kruse, J., B. Poppel, L. Abryutina, G. Duhaime, S. Martin, M. Poppel, M. Kruse, E. Ward, P. Cochran, and V. Hanna. 2008. Survey of living conditions in the Arctic (SliCA). Pages 107-134 in V. Møller, D. Huschka, and A. C. Michalos, editors. Barometers of quality of life around the globe: How are we doing? Springer, New York, New York, USA. http://dx.doi.org/10.1007/978-1-4020-8686-1_5

Magdanz, J. S., R. J. Walker, and R. R. Paciorek. 2004. The subsistence harvests of wild foods by residents of Shungnak, Alaska, 2002. Technical paper 279. Alaska Department of Fish and Game, Juneau, Alaska, USA. [online] URL: http://www. subsistence.adfg.state.ak.us/download/Technical\%20Papers/tp279. pdf.

Martin, S. 2009. The effects of female out-migration on Alaska villages. Polar Geography 32(1-2):61-67. http://dx.doi. org/10.1080/10889370903000455

Martin, S. 2010. Who moves and why: stylized facts about Iñupiat migration in Alaska. Pages 147-161 in L. Huskey and C. Southcott, editors. Migration in the circumpolar North: new concepts and patterns. Northern Studies Press, Thunder Bay, Canada.

McCarthy, J. J., and M. L. Martello. 2005. Climate change in the context of multiple stressors and resilience. Pages 945-988 in Arctic climate impact assessment scientific report. Cambridge University Press, New York, New York, USA. [online] URL: http://www.acia.uaf.edu/pages/scientific.html.

Morehouse, T. A., G. A. McBeath, and L. Leask. 1984. Alaska's urban and rural governments. University Press of America, Lanham, Maryland, USA.

Morgan, L. 1976. Caribou kills: an Eskimo report. Alaska 42 (5):8,77-78.

Ostrom, E. 1990. Governing the commons: the evolution of institutions for collective action. Cambridge University Press, Cambridge, UK. http://dx.doi.org/10.1017/cbo9780511807763

Spaeder, J. J. 2005. Co-management in a landscape of resistance: the political ecology of wildlife management in western Alaska. Anthropologica 47(2):165-178. [online] URL: http://www.jstor. org/stable/25606234.
Spaeder, J. J., and H. A. Feit. 2005. Co-management and indigenous communities: barriers and bridges to decentralized resource management-introduction. Anthropologica 47(2):147-154. http://dx.doi.org/10.2307/25606232

State of Alaska. 2011.2009 Alaska economic performance report. Division of Economic Development, Department of Commerce, Community, and Economic Development, Anchorage, Alaska, USA. [online] URL: http://commerce.state.ak.us/ pub/2009 Performance Report web.pdf.

Timmerman, P. 1981. Vulnerability, resilience and collapse of society: a review of models and possible climatic applications. Environmental monograph 1. Institute for Environmental Studies, University of Toronto, Toronto, Canada.

Turner, B. L. II, R. E. Kasperson, P. A. Matson, J. L. McCarthy, R. W. Corell, L. Christensen, N. Eckley, J. X. Kasperson, A. Luers, M. L. Martello, C. Polsky, A. Pulsipher, and A. Schiller. 2003. A framework for vulnerability analysis in sustainability science. Proceedings of the National Academy of Sciences 100 (14):8074-8079. http://dx.doi.org/10.1073/pnas.1231335100

U.S. Bureau of the Census. No date. Number of inhabitants: Alaska. U.S. Department of Commerce, Washington, D.C., USA. [online] URL: http://www2.census.gov/prod2/decennial/ documents/41601749v2p51-54ch2.pdf.

U.S. Bureau of the Census. 1993. Census of population and housing, 1990: summary tape file 3D. ICPSR06012-v1. Interuniversity Consortium for Political and Social Research, Ann Arbor, Michigan, USA. http://doi.org/10.3886/ICPSR06012.v1

U.S. Bureau of the Census. 1996. Census of population and housing, 1970: summary statistic file 4b: population. U.S. Department of Commerce, Washington, D.C., USA. Interuniversity Consortium for Political and Social Research, Ann Arbor, Michigan, USA. http://doi.org/10.3886/ICPSR08127.v1

U.S. Bureau of the Census. 2008. Census of population and housing, 1980: summary tape file 3D. ICPSR08157-v1. Interuniversity Consortium for Political and Social Research, Ann Arbor, Michigan, USA. http://doi.org/10.3886/ICPSR08157.v1

U.S. Bureau of the Census. 2002. Census of population and housing, 2000: summary file 2, Alaska. ICPSR13234-v2. Interuniversity Consortium for Political and Social Research, Ann Arbor, Michigan, USA. http://doi.org/10.3886/ICPSR13234

U.S. Bureau of the Census. 2012. Profile of general population and housing characteristics: 2010 demographic profile data. U.S. Department of Commerce, Washington, D.C., USA. [online] URL: http://factfinder.census.gov.

VanStone, J. W. 1960. A successful combination of subsistence and wage economies on the village level. Economic Development and Cultural Change 8(2):174-191. http://dx.doi.org/10.1086/449835

Western Arctic Caribou Herd Working Group. 2003. Western Arctic caribou herd cooperative management plan. Western Arctic Caribou Herd Working Group, Nome, Alaska, USA.

Wilson, G. A. 2012. Community resilience in environmental transitions. Routledge, Abingdon, UK. 
Woodford, R. 2012. Alaska's largest caribou herd is declining. Alaska Fish and Wildlife News June 1. [online] URL: http://www. adfg.alaska.gov/index.cfm?adfg=wildlifenews.view article\&articles $\mathrm{id}=560$

Wolfe, R. J. 2004. Local traditions and subsistence: a synopsis from twenty-five years of research by the State of Alaska. Technical Paper 284. Alaska Department of Fish and Game, Juneau, Alaska, USA. [online] URL: http://www.adfg.alaska.gov/ techpap/tp284.pdf.

Wolfe, R. J., C. L. Scott, W. E. Simeone, C. J. Utermohle, and M. D. Pete. 2009. The "super-household" in Alaska Native subsistence economies. Final report to the National Science Foundation. ARC 0352611 .

Wolfe, R. J., and R. J. Walker. 1987. Subsistence economies in Alaska: productivity, geography, and development impacts. Arctic Anthropology 24(2):56-81. [online] URL: http://www.jstor. org/stable/40316144.

Young, O. R., F. Berkhout, G. C. Gallopin, M. A. Janssen, E. Ostrom, and S. van der Leeuw. 2006. The globalization of socioecological system: an agenda for scientific research. Global Environmental Change 16(3):304-316. http://dx.doi.org/10.1016/ j.gloenvcha.2006.03.004 